\title{
Administrative System in Punjab during and after Ranjit Singh: A Case Study of Multan
}

Ahmad Ali*, Muhammad Akbar and Khizar Hayat

The Islamia University of Bahawalpur, Pakistan

\begin{abstract}
An ideal and successful ruler is one who, to make his kingdom a peaceful State, established strong, organized and durable institutions. State institutions or pillars are considered the backbone in stability of the State. Three pillars or institutions, which are necessary for an organized as well as everlasting government and better economy, are legislature, executive and judiciary. Without empowering these institutions, governmental system cannot run for a long time. Though Ranjit Singh, due to his power, intelligence and great struggle, founded a glorious dynasty, yet he failed to form these basic institutions properly. It is a fact that only institutions run the government not men because personalities come and go whilst the institutions exist. It is also true that these institutions existed in any shape, but they were totally under the control of the Maharaja. Judicial courts were established, but they were not only under the direct control of the Maharaja but also too weak to work. Besides a central court, every province had a big legal court under the governor. Similarly, some other small courts were established in every Pargna where Kardars, Chaudharys and Punch settled the disputes of the native people. Sometimes, the governor could alter the decision of these authorities whilst the Maharaja had a right to modify governor's decisions. Strict punishments were not exercised on dangerous crimes which created law and order situation. To ignore the bad financial condition of the subjects, he invented and introduced innovative procedures for collecting revenue and no proper arrangements were made for the betterment of the masses. The main purpose of collecting revenue was to pay the salary of the army and fulfil other requirements so that the aim of expansionism could be achieved. There was not any check and balance on Kardars and they were free to collect revenue in accordance with their desires. At a time, they were given the powers of a judge, a revenue collector as well as an administrator.
\end{abstract}

Keywords: Daftar; Ranjit Singh; Sawan Mal; Kardars; Civil secretariat

\section{Introduction}

In the Punjab, the definite Sikh regime began when Ranjit Singh assumed control at Lahore in 1799 . He originated the commonwealth in 1801. Contrasting Indian monarchs, who nominated the Brahmins as their minister, he employed Fakir Aziz-ud-Din as his prime minister. His management contained in all religions, even European Christians. Ranjit's civil government shall seem ambiguous, unpolished, unsystematic or repressive, yet it assisted to alleviate the ills of the later primitive period and endorse the prosperity of his masses. His government may be called a modified military autocracy based. $\mathrm{He}$ irrespective of faith or class, picked his own ministers, governors and the counsellors of confirmed trustworthiness and commitment [1]. The Muslims, the Hindus and even Christian, who gained Ranjit Singh's assurance, were entrusted with the task of leading the kingdom. They were permitted to remain in authority so long as they stayed effectual and proficient in the kingdom. As per civil services, there was neither central or imperial nor provincial service [2]. A prerequisite number of officers were hired by the State at the centre as well as in the provinces. Some present historians opine that Ranjit Singh was a brutal despot in all three estates, Legislature, Executive and Judiciary. By nature, he was not a sound liable towards authoritarianism. If he struggles to be so, his surroundings were not such as to license of it. He competently merged the several trivial principalities into a realm. Unlike Akbar, he did not evolve a perpetual secretarial system to sustain his deed. He could not introduce an appropriate structure to amalgamate and harmonize the working of his quite dispersed provinces. He, due to engage in military missions, could not attend the executive feature for constancy of his kingdom. He, however, did launch some feasible approaches of governance to the political and social milieu of his people.

\section{Statement of the Problem}

During the Misl age, being a simple and unsophisticated governmental structure, there was no need of an extravagant Secretariat. A few peculiar assistants like the Diwan, the Toshahkhana and Munshi were essential. He followed this exercise for a few years, but, as his zones grew broader, the problems of finance, revenue and administration also became intricate. Bhawani Das set up twelve Daftars where the military and civil functions of the Government were carried. The evolution of the Daftars, however, was slow but a gradual process. So, keeping these entire scenarios in mind, we decided to write a research article entitled "Administrative System in Punjab during and after Ranjit Singh: A Case Study of Multan".

\section{Significance of the Study}

In the late $18^{\text {th }}$ century, the formation of the Sikh rule in the Punjab resulted in removal of the Mughals and Afghans. The new governing class was composed of Jats and the non-Jats. Non-Jats were signified among the sovereign class whilst non-Sikhs were the Muslim and the Hindu Jagirdars. Ranjit Singh's all reigning class, belonging to various religions, regions, races and nationalities, was varied in its arrangement. In terms of its ratio, the Sikhs were 49 percent, the Muslims 16 percent, the Hindus almost 29 percent and Christians constituted about 6 percent of the total [3]. He never depended upon the expelled chiefs

*Corresponding author: Ahmad Ali, Lecturer at Govt. Degree College Mailsi, The Islamia University of Bahawalpur, Pakistan, Tel: +92 9250243 9250241; E-mail: prof.aamughal786@gmail.com

Received February 08, 2018; Accepted February 15, 2018; Published February 22, 2018

Citation: Ali A, Akbar M, Hayat K (2018) Administrative System in Punjab during and after Ranjit Singh: A Case Study of Multan. Arts Social Sci J 9: 336. doi: 10.4172/2151-6200.1000336

Copyright: (c) 2018 Ali A, et al. This is an open-access article distributed under the terms of the Creative Commons Attribution License, which permits unrestricted use, distribution, and reproduction in any medium, provided the original author and source are credited. 
[4]. He added a fresh group to the aristocracy and these aristocrats were picked up on the basis of their excellence and capability. They were given imperative places in the civil management as well as the armed forces. From non-aristocratic family, a number of the Muslims, the Sikhs and Hindus was picked up to assist the State [5]. These individuals, such as Gurmukh Singh, Hari Singh Nalwa, Diwan Sawan Mal, Majithia and Attariwala families, were holding the highest status [4].

\section{Hypothesis/Research Questions}

1. The badness or goodness of a particular managerial pattern was a mathematical relationship of inputs to outputs. Where the former was maximized and the later was minimized.

2. Unlike the managerial approach, which strained what public administration should be, the political approach established from an analysis of superficial empirical reality.

\section{Literature Review}

Governmental setup of Ranjit Singh's kingdom was classified into two types. First, central government, which was under his direct control whilst other was under the autonomous Jagirdars who paid a fixed amount to the central government annually. He sensed the requirement of a sturdy federal State with distinct political borders [6]. He had an overriding Secretariat and a panel of ministers, but no parliament. He stayed constantly busy in diplomacy and war and devoted his contemplation in gathering revenue. He increased many direct and indirect sources of taxation on houses, lands, exports and imports. He was forced to bind his endeavours to the preservation of a practical system of management rather than preemptive legislation. $\mathrm{He}$ was pragmatic to those enhancements which were away from inordinate minds. We find despotism without rigorous, a dictator deprived of meanness and administrative system far away from the local institutes of the East. His governmental system may be designated as a blend of unpolished and highly asymmetrical practices like the regime of the Sikh Misls [7]. The overall impression amongst the historians is that the departmental body began in 1808 [8]. Yet, this is not true. Following Daftars were existed during the whole period of the Sikh Empire [9].

\section{Administrative Department under Ranjit Singh}

According to Mufti, Daftar Sarishta-e-Hazoor may be called a regal or Maharaja's own institute. It was established in 1803 to control general expenses and income [10]. Its duty was to communicate the Maharaja with the chiefs of other States and high foreign notables. This office was also responsible to keep the Maharaja's special seal. Without this seal, no command was implemented. The Diwan's office charged a definite amount for placing this seal on each document. The guardian of this stamp was paid a static amount annually from the central bank. Its other branches were as under [10].

First branch was Daftar Roznamcha. It was recognized in 1816 to debit and credit the entries by the treasure in relating with varied items under different heads. Later on, the articles entered in the Roznamcha were dispatched to their suitable heads. This was regulated by Abdul Karim [11].

Daftar Moharyani, the second branch, came into being in 1816, with the seal "Akal Sahai Mohr Daftar-i-Mubarak", under the title of "Mohrin-Motabiq-e-Amar-e-Ala Shudh" or "Sabte Sarishta-i-Moharyani". Its main function was to attach the royal seal and receive commissions on official papers of payments. Its third branch was named Daftar Maliyat (Abwab-ul-Mal). The purpose of this Daftar was to measure the records of the revenue receipts and other resources of earnings [9].
Daftar Jama Kharch-e-Pargna or Talluqa was the fourth branch. This Daftar upheld the records of the land revenue gathered from the Pargnas or Talluqa.

Another branch was Daftar Jama Kharch-e-Sairat. This belonged to the earnings from octroi duties and taxes from salt mines. Daftar Wajohat-e-Muqarari was also one of its main branches [12]. This reserved the records of income from the earnings of court fees ${ }^{1}$ or justice. The receipts were gathered in various methods. For example, definite charges were imposed on the compensation of complaints by means of judicial verdicts. Penalties paid to redress for illicit acts. There were the proceeds from the numerous duties imposed on appeals by the people to the ruler or the ministers. Similarly, on all brands of private agreements, the costs made for the affixing of the Royal Seal.

Similarly, Daftar Abkari involved all duties enforced in the sale of Bhang, Opium, Intoxicating drugs and Spirits. The revenue derived from this resource was relatively unimportant. Besides this, Daftar Chaukiyat dealt with the taxes imposed on all products irrespective of their origin or target. Constant tariffs were fixed on all objects without making a difference between necessity and luxury products [13]. Another important branch was Daftar Nazrana. It dealt with the earnings from the gifts. It was also a compliment paid to the monarch on various events by the people especially by conspicuous dignitaries. It was in the shape of a stable charge from a subordinate tribal chief and sometimes, it was given to the subjugator by the beaten chief for the maintenance of the region [14]. Nazr was rewarded to the Maharaja which had been placed in two classes. First, the static amount that was funded by the minor chiefs and the second contained gifts at court. It was given in the form of horses, cash, swords and shawls. Ranjit Singh obtained 80000 rupees from Bahawalpur. Similarly, he also got same amount and a number of horses from Multan Vakil. Besides this, he received 16 canons and 25000 rupees from Jahandad Khan as Nazrana. During the same year, Damudhar, the Vakil of Kabul, offered Nazrana of 50000 rupees and several horses [15].

Daftar Zabti was also a medium of substantial income, which was obtained from aberrant officials with penalties of assets. Sometimes, these were either recollected by the State or re-awarded to the others in the form of cash. In specific circumstances, it also withdrew the endowments of land from the descendants of late Sardars. Similarly, Daftar Toujehat was established to regulate the accounts of military and regal household. Besides this, Daftar Akhrajat belonged to the expenses of the imperial household. It contained Inaam, Ibtiya, Astabal, Istemal, Tameer, Tahaaif, Khillat, Khurish Feel, Dharmarth, Ziyafat, Tama Sher, Macula Saggam, Jagiraat, Langar Khas, Kiraya, Musaedat and Madid Kharch [16].

Second department was Daftar Mawajib. It dealt with payment for the royal family and departments. This office sustained the records of payments and other remunerations of the government sectors, such as the civil staff, the army and clerical institution. In order to handle with the inflammation work and enlargement of the military and civil establishments, this department was delimited in Mawajib-e-Fauj-iSawari, Mawajib-e-Piyada-e-Mutayyan-e-Qalajat, Mawajib-e-Sair-iJamaat and Mawajib-e-Amla [9].

Third institution was given the name of Toshahkhana-e-Khas. Literally, it was a storeroom or a compartment where rare and cherished objects were kept. It was recognized in 1818. Its head was called Toshahkhania. During the supremacy of Ranjit Singh, Misr Beli Ram was its incharge for almost seven years [9]. Dewhriwala, the

${ }^{1}$ This tax is equivalent to stamp tax of present time. 
guardian of this office, was a well-reputed person by Ranjit's household institution [10]. This institution, preserved distinct records of the Zare-Naqad and the Zar-e-Jins, ${ }^{2}$ kept in its guardianship from time to time [17]. This department also looked after the making of the new articles and repair of old ones. Since its permanent establishment, a number of engravers, skilled artisans and goldsmiths were employed [17]. The distinctive and invaluable Kohinoor diamond was also well-maintained in this department [17].

Fourth department was constituted in the name of Bahla Toshahkhana. It was completed in two phases. First time during 181635 whilst, for the second time, during 1841-46. It belonged to the papers concerning to Toshahkhana Khas. These papers were included only one packet, which neither complete nor very comprehensible.

Daftar Shahzada was considered the fifth department. This department seems to have invented in 1821 with the seal "Sabte Sarishta-e-Shahzada 1878".This retained the accounts of the earnings and spending of the Jagirs and assignments of the royal princes [9].

The sixth office was Daftar Darogha. It was established to look after the custom, octroi and excise duty receipts. The stamp of this Daftar, engraving with "Ram Dayal", was stuck under the description of Sabte Daftar-i- Darogha [12].

The seventh office was belonged to Daftar Mualla and Daftar Khas. Daftar-i-Mualla was a kind of Supreme Department, which was formed during 1822-23 with the stamp "Sat Guru Shahai Khurm Rai" engraving with the Caption of "Mundiraj Daftar-i-Mualla Shudh". It administered the entire work of the monetary management. It had two seals "Akal Sahai Daftar-i-Khas 1880" and "Akal Sahai Diwan Singh" under the Slogan of "Tahreer Yaaft" [18]. Khushal Singh was the first to hold this office and nobody could meet Ranjit Singh except through him. But after some time, some of these Daftars were eliminated and a few merged with others [18].

Daftar Abwab-ut-Tahveel was eighth in number. This department related to the records of financial statements of expenses and income. Ranjit Singh formed reserves in all Pargnas with the mandatory staff. The reimbursement of the salaries was made from the native bank account. Other necessities, in respect of cash, were also met out of the treasury of the Pargna, which were placed in Tahweldar's custody. At first, this sector dealt with financial records of a diverse nature, yet, later on, this encompassed the records of assorted natures such as chief treasury, army, buildings, paymasters, cloth merchants and jewelers etc. [16]. When distinct offices of different administrative branches were established, the function of this office became limited [9]. The records of rifles, shell, guns and gunpowder, which were prepared indigenously, were also reserved in the office of Tahweldars [17].

The ninth department, which was constituted, was Daftar Naqal. This office was recognized in unification with the office for the innovative work and may be assumed as the institution of Sarishta-eHazoor. In legal cases, the Maharaja's instructions were referred to this office [9].

Daftar Mamlikat: was the tenth in number. It dealt with overseas relationships with Cis-Sutlej States, Sindh, Afghanistan, Nepal and East India Company. Fakir Aziz-ud-Din was the head of this department who arranged the drafts in accordance with the Maharaja's directions [19].

${ }^{2}$ The goods and precious metals included gold, silver, utensils of precious stones and the pashmina and exotic goods of Kashmir.
Daftar Wazir: was the eleventh department of Ranjit Singh's Kingdom. All imperative papers, documents and appeals were first inspected by this office and then were sent to the Maharaja for final approval. Dhian Singh, who was the head of this office, implemented the Maharaja's orders.

The last important office was Daftar Religious Endowments. The function of this office was to convert the Maharaja's oral and Punjabi orders into Persian writing by a Munshi. Wherever, there were no Munshis, any other minister or officer noted it and then moved it to the Munshi. The Munshi, later on, converted it into Persian and stamped on it. After that, this order was offered to the Maharaja for endorsement. Although the Maharaja was uneducated, yet he had attained a good awareness of Persian and comprehended the essence of his uttered order. After the approval of a directive, it used to be stamped twice. One had the writing, "Akal Sahai Ranjit Singh" in Gurumukhi script whilst the other had the writing "Molahiza Shudh" in Persian [20].

\section{The Local Management and Government in Multan}

During the Mughal period, Multan was given the status of a complete province, which was divided into three divisions, Multan, Bhakkar and Dipalpur. Besides this, Thathha, which consisted of five Sarkar, ${ }^{3}$ was also counted in Multan. Earlier, Multan was divided into five Pargna but, During the Sikh Kingdom, it was classified into twenty Talluqas ${ }^{4}$ i.e. Luddan, Tibbi, Kahror, Nalah Sadr Wah, Bahadurpur, Kotli Aadil, Punjani, Ghazipur, Khanpur, Khai, Shahpur, Sikandarabad, Shujabad, Sardarpur, Sadaney and Tulamba. Here, all above departments were also performing as it is [21]. At first, the administrator of the province was called Subedar but, later on, this designation was exchanged with the Nazim. Under the Nazim, there was a large number of Mutsaddi, Jagirdars, Ijaradar and Kardars. Mahkma Faujdari, which was working under Faujdar, was established to control the crimes while Mahkma Diwani was in the hands of Qazi and Mufti. For Revenue collection, several Patwari, Korari and Bukhshi were appointed. Qanungo, who was under the Kardar, evaluated their accounts [21].

Ranjit's Kingdom was roughly divided into four Subas, Lahore, Multan (Dar-ul-Aman), Kashmir (Jannat-e-Nazir) and Peshawar. Besides Lahore, Multan and its adjacent territories were under the control of autonomous Jagirdars who paid fixed amount to the central government annually [22]. If we admit a Suba as the key unit of provincial management then we can disregard this philosophy that the entire kingdom was classified into districts [6]. Every Suba was further alienated into Pargnas [8]. The Pargnas were branched out into Talluqa and each Talluqa contained of Mouzas. Mouza was the smallest unit of the Suba. The standard of this classification was administrative suitability, cultural or clannish sympathy and revenue facilities [22].

Multan Suba had a Nazim, who, as a central character, relished a very close assurance of the Maharaja. With the Maharaja's friendliness, he could perform as miniature monarch. The Nazim's office was an appellate court of unique character and the Nazim had appellate authority against Kardars. Next to Nazim was the Kardar who was usually selected by the Nazim [23]. He was the head of a Pargna of the province and whose headquarter, in perspective of management, was more imperative. With massive authorities, he was really a replication of monarch in the centre. He administered land revenue and considered as revenue collector, an accountant, a magistrate or a judge, and an excise

${ }^{3}$ Sarkar was the name of a sub-division or a division and commonly known as Pargna.

${ }^{4} \mathrm{~A}$ Talluqa was an administrative district for taxation purposes, typically comprising a number of villages. 
officer as well as a customs officer. He used to submit the petitions to the Nazim. He was the most imperative and profoundly burdened State officer who had all collective powers of an evaluator and a well-being officer. Due to the vast administrative authorities, he had enjoyed much power than the Nazim [8]. He was without any permanent stipend and commonly lived on congestion. His leading role was to gather revenue and to credit the balance in the State treasury instantly. Diwan Mulraj kept his Kardars in good order, but he had full control of them. They were not allowed to plunder. Their Violence had been placed at his door [24].

In Multan, Sawan Mal was a Kardar and a big Ijaradar too. Another interpretation was that the entire territory was slightly divided into the districts. This Suba contained the localities of Multan, Dera Ismail Khan, Leiah, Dera Ghazi Khan, Muzaffargarh and some parts of Jhang [2]. It consisted of various Pargnas which further divided into Talluqas. There were fifty or hundred villages or Mouzas in a Talluqa. More than one Kardars were appointed in a big Pargna. The smallest administrative unit was called a village, in which Punchayat system was enforced.

A vital feature of the indigenous management in Multan was the Punchayat which existed in every Mouza and enjoyed inclusive supremacies. It was possessed of so much sacredness that no party dared to tell a lie before it. Each Mouza was an autonomous unit in which land was detained by the inhabitants on Bhaichara basis. ${ }^{5}$ Although, there was not a police department during the entire Sikh kingdom, yet Kotwal was responsible to maintain law and order situation [2]. It, to a great extent, was devastated for many years due to mismanagement and warfare [6]. Property and life were unreliable and the populace, which once had been abundant and rich, had been ruined. Kotwal was the principal police officer who, usually a Muslim, enjoyed broader powers to sustain law and order $[6,25]$.

After the conquest of Multan, a new era began in which civil rulers, Afghan army, theologians and traders were substituted by the civil administration as well as the Punjab army and the Akalis. With the seizure of Multan, its flourishing chapter started [23]. At the time of natural catastrophe, such as hunger deaths, the scarcities, a slum in the industry or agrarian and horticultural disasters, its residents were permitted to go and settle down any place in the Punjab. New regions and colonies were set up in Dera Ghazi Khan, Muzaffargarh, Leiah, Dera Ismail Khan, Mailsi, Kahror Pacca, Pakpatan, Sahiwal, Jhang and Rajanpur etc. People were relaxed without any terror or emotions of being non-Punjabis. The artisans, labourers and the clerks had found jobs effortlessly. At the arrival of the new government, there was a sense of relief, safety and gratification amongst them because they had been remained humble slaves for several centuries and suffered religious, military and politico-economic massacres [22].

No one can reach a decision with the prejudiced interpretations that even thriving governors could not gratify Ranjit Singh's demands in getting the fixed payments than peripheral contentment to the producers of Multan. It is supplementary that governors were terminated for not dispatching higher revenue to Lahore Durbar and the same is the case with Multan during the early period. From 1818 to 1821, Ranjit Singh discharged six governors. Such sturdy decisions were eye-openers to the consecutive governors of Multan. As a result, Sawan Mal and Mulraj performed their duties in their best manner and they arose Multan at its peak in socio-economic, civil, military and political fields [26].

Ranjit Singh's major concern in Multan, with a vision to grant

It is noteworthy that, in Lahore, the admin was classified into Muhallas which was supervised by a native leading person. socio-economic and religious sovereignty which was previously denied, was to offer a secular, effective and generous executive machinery. In his kingdom, it was not a small act to unite the regions and their people and save them from repressive events of the reigning class. To rescue the people of Multan by endowments and reduction of revenue, who were below the poverty line, was an admirable step. Lapses are found all over the world under any format, but we have to read these administrators and governor's activities in the light and the background of the political environment in the later primitive age whether the Mughal or the Pathan or even the Sikh regime [27].

As a Governor, Sawan Mal showed a colossal perimeter with respect to the diligent work and caused extraordinary changes. He offered many modifications. Under his administration, the approach of broad development was a noteworthy achievement in the history of Multan. His real changes and plans, which made him a unique ruler and the most effective governor, will be discussed in the next chapter. Yet, there had been three solemn flaws in the administration of Multan, which were accountable for so called domination after Ranjit's death. First, there was no official check on the Kardars. Secondly, Kardar was so overloaded with miscellaneous duties that numerous imperative matters had gone into the hands of his subordinates [28]. They were poorly rewarded and hence had no inducement working correctly with energy and passion.

Finally, the delegation of infinite powers involved them to feather their own nests at the price of the community. In fact, the idea of parting of powers never happened in the minds of all the rulers of the Subcontinent. So, it is on record that even the accumulators of the East India Company also expected both judicial and administrative commands. In Multan, officials acted well without any terror during Ranjit's era, but after his death, innate imperfections began to seem. Not only in Multan but also in other parts, the public was behaved as cows to be milked for the advantage of government or Kardar. But we should not disremember that, in such a condition, this kind of events were nearly a worldwide phenomenon [29].

Briefly, Ranjit Singh paid much attention to the rulers of Multan to recognize his suzerainty. It was a chunk of his general approach to claim suzerainty over self-sufficient chiefs as a prelude to the extension of their territories. He possessed Multan along with Peshawar, Dera Ghazi Khan, Bannu and Dera Ismail Khan too. He tended the devolution of powers to the Nazims, Diwans, Thanadars, Jagirdars and Kardars and separated them from Chaudharys, Amils, Muqaddams ${ }^{6}$ and Zamindars [30]. He, in the name of Sawan Mal, delivered an instruction to give an endowment of a town worth one thousand rupees to Hukmnamia Sikhs in Multan [31]. These authorities proved this fact that he had control over Multan and designated his own Nazim [32].

\section{Data Analysis/Conclusion}

The Sikh regime was a landmark in the history of Punjab and Multan because it considered a secular State. After six long centuries of Muslim rule, it passed into the hands of the Hindus in 1818. The Sikhs were not enlightened masters, yet the Hindus and Muhammadans considered their reign better than the Afghans. Ranjit's court was full of ministers and bureaucrats, yet they were not capable to make proper legislation. Provincial administration depended upon his liking and disliking. He, whenever and whoever, could terminate from his post. We never opined that the Sikh rule was benevolent and good, but it, at any rate, was better than the Pathans. During the Sikh rule in Multan, there is no doubt

${ }^{6}$ It can be called a lambardar, who collects the dues under lambardari or Bisw system. 
Citation: Ali A, Akbar M, Hayat K (2018) Administrative System in Punjab during and after Ranjit Singh: A Case Study of Multan. Arts Social Sci J 9: 336. doi: $10.4172 / 2151-6200.1000336$

Page 5 of 5

about the standard of life of all the classes. It, to a great extent, was the legacy of the Mughals and the Afghans who committed numerous atrocities. During this period, when medieval age was bidding farewell, the Sikh administrators left behind the old superstitions. People, with feelings of the old slavery, isolation and inferiority complex, came closer to the modern world and attracted to the outside visitors and businessmen. As a matter of fact, the public had been provided basic rights like freedom of movement, human touch in State administration, opening a large avenue of employment, recognition of talent and merit, end of religious persecution and economic exploitation, trade and provision of the necessities of life. Indeed, under the secular despotic Sikh rule, their predictions appeared quite positive and encouraging. They were the first to bring peace and order and sometimes even minor irrigation facilities in Multan.

\section{References}

1. Khilnani N (1951) The Punjab under the Lawrences Shimla: The Punjab Government Record Office.

2. Sinha NK (1933) Maharaja Ranjit Singh Calcutta: A Mukherjee Publication.

3. Banga I (1982) The Ruling Class in the Kingdom of Lahore Amritsar: Guru Nanak Dev University.

4. Sharma R (2001) The Lahore Durbar Amritsar: Guru Nanak Dev University.

5. Grewal J (1981) The Reign of Maharaja Ranjit Singh: Structure of Power Economy and Society Patiala: Punjabi University.

6. Malik IA (1990) Tareekh-e-Punjab Lahore: Salman Matboaat.

7. Burnes A (1834) Travels into Bokhara (Vol 1) London: John Murray.

8. Hasrat B (1977) Life and Times of Ranjit: A Saga of Benevolent Despotism Hoshiarpur: VV Research Institute.

9. Singh G (1939) Maharaja Ranjit Singh First Death Century Volume Amritsar: Khalsa College.

10. Mufti A-u-D (1963) Ibratnama Jullundur: Raj Publishers.

11. Steinbach LC (1883) The Punjab: Being a Brief Account of the Country of the Sikhs Patiala: Languages Department.

12. Kohli SR (1919) Catalogue of Khalsa Durbar Record (Vol 1) Lahore: Punjab University.
13. Singh B (1990) Maharaja Ranjit Singh and His Times New Delhi: Sehgal Publishers.

14. Suri SL (1974) Umdat-ut-Tawarikh (Vol 3) (V Suri Trans) Chandigarh: Guru Nanak Dev University.

15. Singh GG (1970) Tawarikh Guru Khalsa (Vol 2) Patiala: Bhasha Vibhag.

16. Kohli SR (1931) Catalogue of Khalsa Durbar (Vol 3) Lahore: Punjab Government Printing Press.

17. Kohli SR (1923) Catalegue of Khalsa Durbar Records (Vol 2) Lahore: Punjab Printing Press.

18. Singh DA (1928) Zafarnama-i-Ranjit Singh Lahore: Punjab University.

19. Gupta HR (1991) History of the SIkhs: The Sikh Lion of Lahore Maharaja Ranjit Singh 1799-1839 (Vol 5) New Delhi: Munshiram Manoharlal Publishers.

20. Waheed-ud-Din FS (1965) The Real Ranjit Singh Karachi: Lion Art Press.

21. Gilani SM (1938) Muraqqa-e-Mooltan Lahore: Jazib Publishers.

22. Chhabra G (1962) The Advanced History of the Punjab (Vol 2) Ludhiana: Prakash Brothers.

23. Hugel BC (1845) Travels in Cashmere and the Punjab London: John Murray and Albemarle.

24. Great Britian Parliament (1849) Papers Relating to the Punjab 1847-1849 London: Harrison and Son.

25. Govt of the Punjab (1884) District Gazetteer of Multan 1883-84 Lahore: Arya Press.

26. Moorcraft W (1767) Travels in the Himalayan Provinces of Hindustan and the Panjab; in Ladakh and Kashmir; in Peshawar; Kabul and Bokhara; from 1819 to 1825 New Delhi: Saga Publications.

27. Griffin LH (1893) Rulers of India: Ranjit Singh Oxford: The Clarendon Press.

28. Cunningham JD (1918) A History of the Sikhs: From the Origin of the Nation to the Battles of the Sutlej London: Oxford University Press.

29. Khilnani N (1971) British Power in the Punjab 1839-1858 New Delhi: Asia Publishing House.

30. Gupta HR (1956) Panjab on the Eve of First Sikh War: A Documentary Study of the Political Social and Economic Conditions of the Panjab as Depicted in the Daily Letters. Hoshiarpur: Panjab University.

31. Foreign/Political Proceedings (1852), p: 182.

32. Foreign/Political Proceedings (1847), p: 184 